\title{
Electroversion of lone atrial fibrillation and flutter including haemodynamic studies
} at rest and on exercise

\author{
Leon Resnekov ${ }^{1}$ and Lawson McDonald \\ From The Institute of Cardiology, National Heart Hospital, London W.I
}

Thirty patients with atrial fibrillation and seven with atrial flutter, all of whom were carefully examined to exclude any associated underlying heart disease, were treated by direct current shock. Sinus rhythm was achieved in 24 of the 30 patients with atrial fibrillation; all patients with atrial flutter were brought into sinus rhythm. The incidence of complications was particularly high in those with lone atrial fibrillation and could be related to the higher energy level setting required. No complications occurred in the group treated for lone atrial flutter in whom low energy level settings were uniformly successful. Only 4 patients treated for atrial fibrillation remained in sinus rhythm at the end of a 36-month follow-up. Reversion to the dysrhythmia occurred

within minutes or days of electroversion and the majority who reverted did so within the first month. Quinidine was of little use in maintaining sinus rhythm. In contrast, patients with lone atrial flutter maintained sinus rhythm for a significantly longer period of time.

Four of the patients with atrial fibrillation and 2 with atrial flutter were studied at rest and on graded exercise before and after conversion to sinus rhythm. Clear haemodynamic evidence of the benefit of sinus rhythm was obtained, particularly at the higher levels of exercise which could be related not only to the longer diastolic filling time in sinus rhythm but also to the booster action of atrial systole.

Despite the evidence of haemodynamic benefit in sinus rhythm, it is concluded that there is no indication for attempting to convert asymptomatic lone atrial fibrillation to sinus rhythm by direct current shock. This dysrhythmia is relatively resistant to treatment, complications are frequent, and sinus rhythm is maintained for a disappointingly short time. Patients with lone atrial flutter, however, are converted to sinus rhythm with relatively low electrical energies; complications are therefore fewer and sinus rhythm is maintained more frequently. Thus with lone atrial flutter, electroversion is usually indicated.

r

Direct current shock is more effective than alternating current in the treatment of ventricular dysrhythmias (Lown, Amarasingham, and Neuman, 1962) and more effective than drug therapy in converting supraventricular dysrhythmias to sinus rhythm (McDonald, Resnekov, and O'Brien, 1964). Though an effective form of therapy, potentially serious complications may follow its use (McDonald and Resnekov, 1965; Resnekov and McDonald, 1967), and the length of time that sinus rhythm persists is frequently disappointingly short (Resnekov and McDonald,

Received 2 July 1970.

${ }^{1}$ Address for reprints: Dr. Leon Resnekov, Department of Medicine (Cardiology), University of Chicago, 950 East 59th Street, Chicago, Illinois 60637, U.S.A.
1968). The success of conversion and the length of time that sinus rhythm persists are related to the underlying state of the heart, the cardiothoracic ratio and size of the left atrium, and the duration of atrial fibrillation before treatment (Resnekov, 1965). Patients suffering atrial fibrillation, with no obvious cause for the dysrhythmia, might appear, therefore, to be a particularly suitable group of patients for electroversion. In this communication we document the effects of such treatment in 30 patients with lone atrial fibrillation and 7 patients with lone atrial flutter. In addition, in order to determine whether any haemodynamic benefit would follow conversion to sinus rhythm, 4 of the patients with atrial fibrillation and 2 with 
atrial flutter were studied haemodynamically at rest and on effort before and after conversion, and the results of these studies are also presented.

\section{Methods}

Thirty-seven patients were studied in whom the dysrhythmia was atrial fibrillation in 30 and atrial flutter in 7 (Table $\mathrm{I}$ ). A diagnosis of lone atrial fibrillation or flutter was made after a careful history, full physical examination, electrocardiogram, and chest $x$-ray, and when the only abnormality that could be detected was the presence of the dysrhythmia. Thus there was no underlying valvar heart disease, either congenital

TABLE I Patients studied

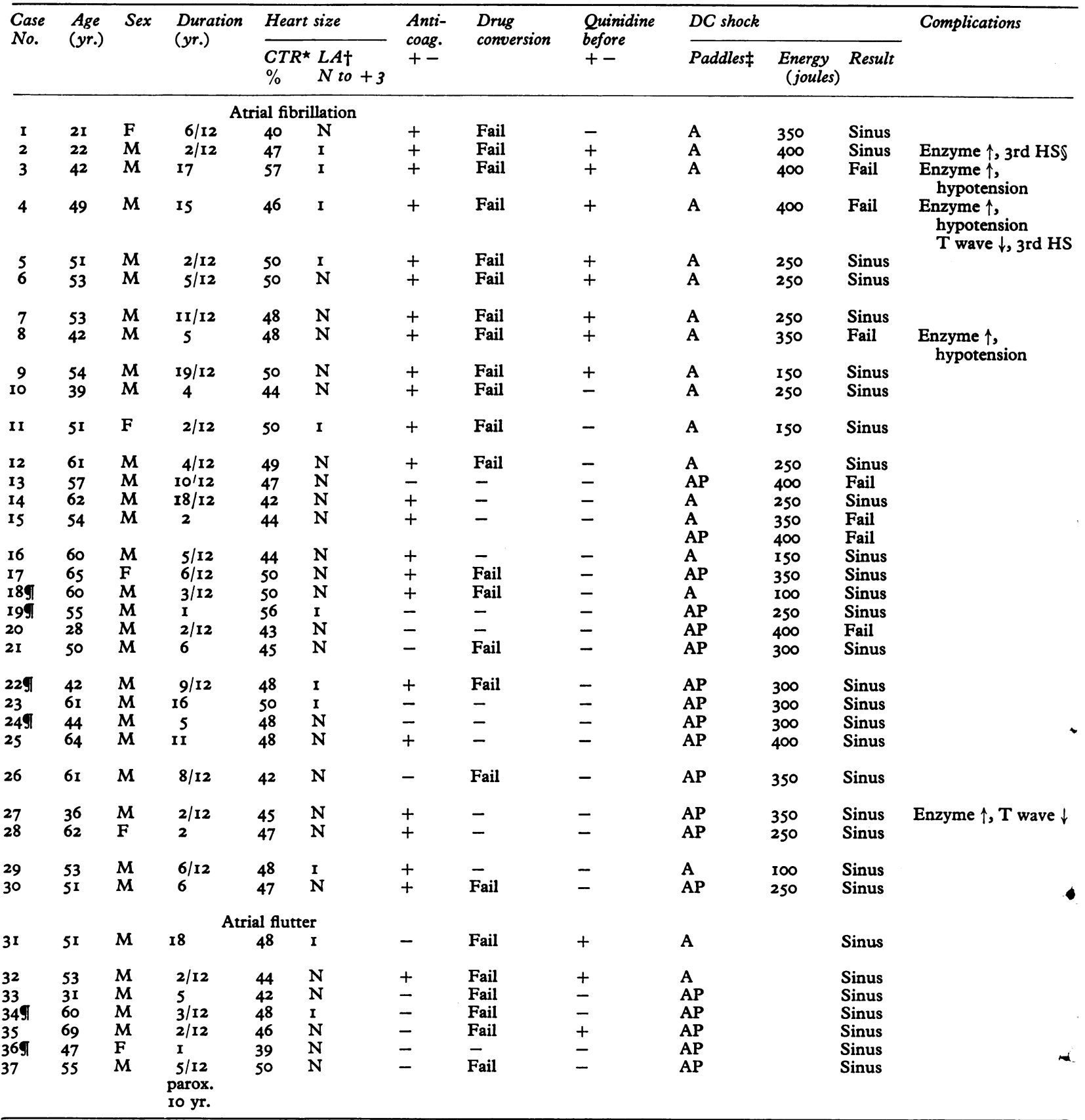


or acquired, no primary myocardial disease, and no evidence of systemic or pulmonary hypertension. A very careful history was taken to detect any symptom suggestive of coronary heart disease, and no patient gave a history of any cardiac disability other than could be explained as being directly related to the dysrhythmia. Nevertheless, it is appreciated that the definite exclusion of

\begin{tabular}{lll}
\hline Quinidine & Sinus rhythm & Comment \\
after & for,+ & \\
+- & still in $S R$ & \\
\hline
\end{tabular}

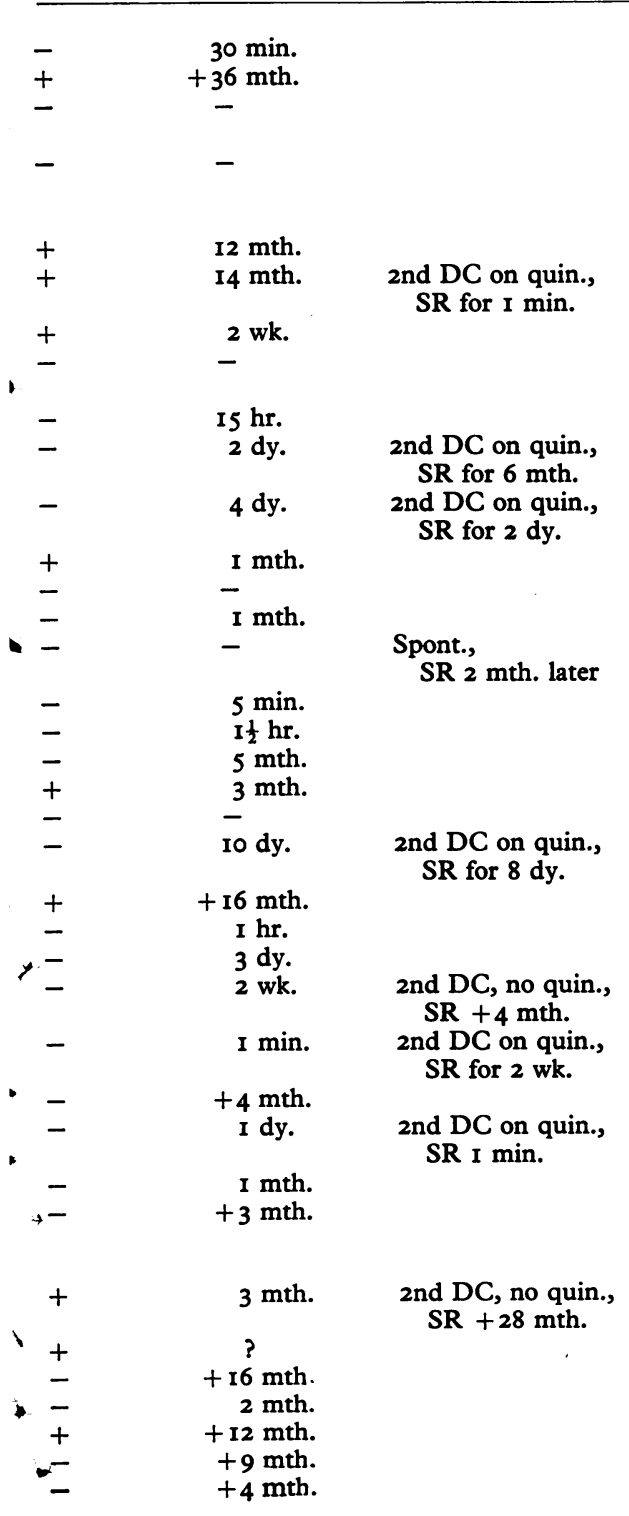

I Patients studied haemodynamically (see Table 5). coronary heart disease despite a careful history, physical examination, and electrocardiographic assessment may be difficult. Thyroid function tests were performed routinely on all patients, and no patient had evidence of hyper- or hypothyroidism. No patient gave a history of atrial fibrillation or flutter in any other member of the family. All the patients presented were in established atrial fibrillation or flutter, and none was thought to have a paroxysmal atrial dysrhythmia. Three chest radiographs were taken before and after treatment, a postero-anterior view, a lateral view (right), and a penetrated anteroposterior grid view at $122 \mathrm{~cm}$. to indicate the size of the left atrium. The electrocardiogram and chest radiographs were repeated on the day after treatment, and sometimes on the second day after treatment if there had been a significant alteration in heart size after the direct current shock. The overall size of the heart was estimated by the cardiothoracic ratio (Danzer, 1919), and the left atrium graded from a penetrated antero-posterior grid view into normal $(N)$, slight $(+I)$, moderate $(+2)$, and severe $(+3)$ enlargement (Resnekov, 1965). The erythrocyte sedimentation was measured by modification of Westergren's technique (Dawson, 1960) on the day before and the day after treatment. Serum levels of glutamic oxaloacetic transaminase were measured by the Sigma-Frankel Method (Broida, 1956, I96I), and of lactic dehydrogenase by the technique of Berger and Broida (1957, 1960). The sedimentation rate and levels of the serum enzymes were repeated daily until control levels returned. Blood urea levels and levels of serum electrolytes were measured in all patients receiving diuretic therapy. The duration of anticoagulant therapy was noted and the thrombotest (Owren, 1959) performed to ascertain that the level of control was satisfactory, and if necessary the dosage was readjusted. The height and weight of each patient were measured and the body surface area determined from the nomogram prepared according to the formula of Du Bois and Du Bois (1916).

Electroversion was performed using methods already described (Resnekov and McDonald, 1968). Digoxin or other digitalis preparations were withheld for at least 24-48 hours before treatment. Quinidine, 300-mg., was given orally or intramuscularly $I_{\frac{1}{2}}$ hours before treatment to many of the patients (Table I). Premedication was used only in unusually anxious patients and consisted of 50-75 mg. pethidine and was followed by anaesthesia induced by a slow intravenous injection of a sleep dose of 2.5 per cent sodium thiopentone or I per cent sodium methohexitone maintained with 70 per cent nitrous oxide and 0.5 per cent halothane as required (Gilston, Fordham, and Resnekov, 1965). Electrical energies were delivered using two anterior or one anterior and one antero-posterior paddle, starting with an energy level setting of 50 joules increasing by 50-joule increments until successful electroversion occurred or until 400 joules had been delivered (see Table $r$ ). With the development of sinus rhythm or failure to achieve 
sinus rhythm, the anaesthetic was discontinued and a 12-lead electrocardiogram taken. Subsequently, patients were taken to the intensive care unit or returned to their wards, but in either case oscilloscopic monitoring of the electrocardiogram was maintained for 24 hours or longer and a record of the blood pressure maintained every half hour if hypotension had occurred.

Four patients treated for atrial fibrillation and two for atrial flutter were studied haemodynamically at rest and on effort according to methods previously described (Resnekov, 1965, 1967). In summary, a $130-\mathrm{cm}$. length of Portex tubing size $\mathrm{FG}_{3}$ (external diameter $\mathrm{I} \cdot 02 \mathrm{~mm}$., internal diameter $0.80 \mathrm{~mm}$.) was passed percutaneously into an arm vein through an r8-gauge thin-wall Yale needle and advanced slowly to the pulmonary artery. Pressure measurements were taken to confirm that the tubing lay in the chosen site. An $80-\mathrm{cm}$. length of Teflon tubing size TFro (external diameter $\mathrm{I} \cdot 0 \mathrm{~mm}$., internal diameter $0.60 \mathrm{~mm}$.) was passed by the technique described by Seldinger (1953) over a nylon guide wire introduced into the brachial artery on the same side as the venous catheter via a 19-gauge thin-wall Riley needle and advanced for about $30 \mathrm{~cm}$. The patient was then asked to sit on a bicycle ergometer (Elema Corporation) with the pulmonary and brachial arterial catheters in position, and pressure recordings were made with reference to the sternal angle using two strain gauges and a multichannel recorder. The electrocardiogram was recorded simultaneously with the pressures, and once a steady state had been achieved cardiac output was determined by the Fick method. Exercise was then started and performed for six minutes at each of three work loads, and pressures and the electrocardiogram were recorded each 30 seconds but displayed continuously on the oscilloscope. During the last two minutes of each work load, expired air was collected simultaneously with blood samples from the pulmonary and brachial arteries. Expired air was analysed by a micromethod for oxygen and carbon dioxide content (Scholander, 1947), and the oxygen content of mixed venous and arterial blood determined by the manometric method of Van Slyke and Neill (1924), the cardiac output calculated, and the stroke volume derived. The physical work capacity at a heart rate of 170 beats $/ \mathrm{min}$. $\left(\mathrm{PWC}^{170}\right.$ ) (Sjöstrand, 1947) was determined by extrapolation of the relation between heart rate and work load. On the day after the haemodynamic studies, direct current shock was used to restore sinus rhythm. The haemodynamic study at rest and on effort was then repeated in an identical fashion 48 hours after the patient was brought into sinus rhythm, and no patient studied was receiving either digoxin or quinidine. Stroke volume and heart rate were plotted against the work load before and after electroversion to compare the values during the dysrhythmia and in sinus rhythm at equivalent heart rates. All results were analysed statistically and a paired ' $t$ ' test performed (Hill, I966). A follow-up study was maintained for 36 months after conversion.

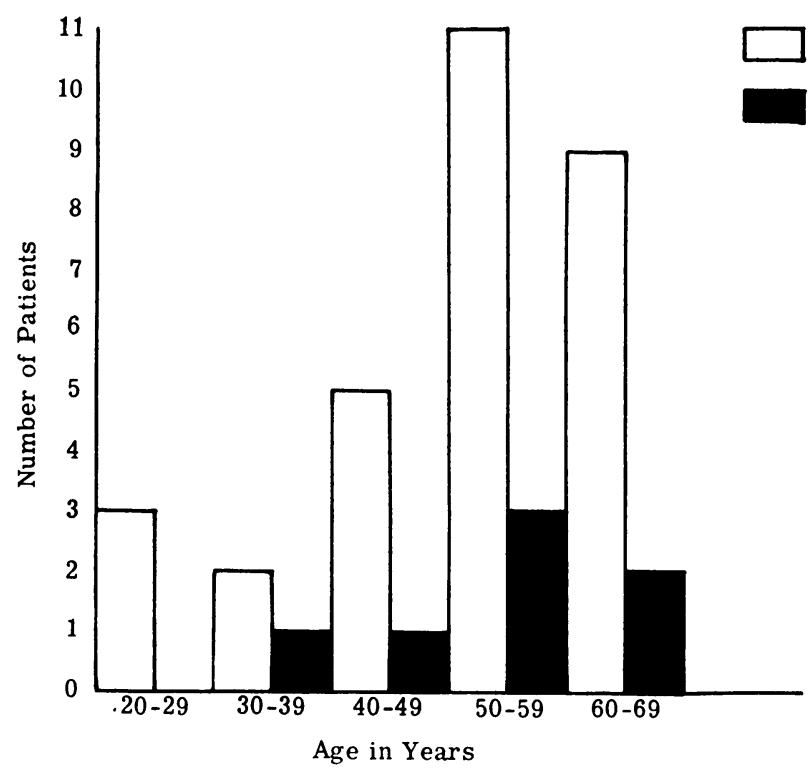

FIG. I Ages and numbers of patients with atrial fibrillation and atrial flutter.

Further attempts to achieve sinus rhythm were made in 8 patients in whom the initial attempt was unsuccessful or in whom the dysrhythmia recurred (Table I).

\section{Patients}

The average age of the patients treated was 50 years for atrial fibrillation (SD I I.8) and 52 years (SD II.8) for the patients with atrial flutter (Fig. I). Of 30 patients with atrial fibrillation, 26 were men, as were 6 of the 7 with atrial flutter. The duration of the dysrhythmia before treatment is shown in Fig. 2. Of the 30 patients with atrial fibrillation, 4 had had this rhythm disturbance for more than ro years.

The radiographic size of the heart is given in Table $r$. The cardiothoracic ratio exceeded 50 per cent in only one patient, in whom atrial fibrillation had been present for more than 17 years.

FIG. 2 Duration of atrial fibrillation and flutter before conversion to sinus rhythm.

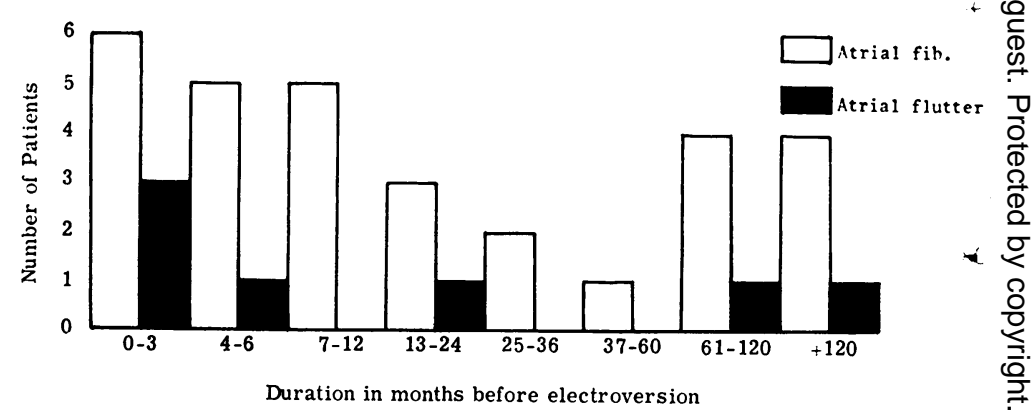




\section{Results}

Sinus rhythm followed direct current shock in 24 of the 30 patients with atrial fibrillation $(80 \%)$ and in all 7 of the patients with atrial flutter. Atrial fibrillation had been present for two years or longer in 4 of the 6 unsuccessfully treated patients; in 2 it had been present for 15 and 17 years, respectively. The giving or withholding of quinidine before electroversion did not appear to be important

Ty the success or failure of treatment.

Electrical energy for successful conversion The electrical energy levels required for electroversion are given in Fig. 3. Of the 24 patients with atrial fibrillation, Io required a setting of 300 joules or more. No - patient with atrial flutter required an energy setting in excess of 200 joules, and 6 were brought into sinus rhythm with settings of I 50 joules.

Complications Complications were recorded in 5 of the 30 patients with atrial fibrillation ( $16.7 \%)$ and in no patient with atrial flutter (Table 2). These included a rise in the serum enzyme levels in all 5, with hypotension additionally in 3. Two patients developed sharp $T$ wave inversion in serial electrocardiograms recorded after treatment, and in both a loud left ventricular third heart sound developed. All the 5 patients who developed complications were treated with energy level settings of 350 or 400 joules.

Intervening rhythms Intervening rhythms immediately after electroversion were frequent - in the patients with atrial fibrillation (Table 3), 17 episodes being recorded in the 30 .3 patients, and included atrial extrasystoles in 8 , ventricular extrasystoles in 6 , a 'wandering 'pacemaker' in one, sinus bradycardia in one, and prolongation of the PR interval in one. Of the 7 patients with atrial flutter, 2 developed - intervening rhythms, one patient developed sinus bradycardia, and one junctional rhythm.

- The intervening rhythms persisted only for one to three minutes before regular sinus rhythm was established in all instances.

Follow-up studies Follow-up studies were undertaken in all 30 patients with atrial fibrillation for up to 36 months and similarly in 6 of the 7 patients with atrial flutter. Of the 24 patients whose atrial fibrillation was conkerted to sinus rhythm, 20 have reverted to atrial fibrillation $(84 \%)$. No fewer than 7 reverted within the first 24 hours (Table 4) and 16 of the 20 patients did so within the first month (Fig. 4). Of the 6 patients with

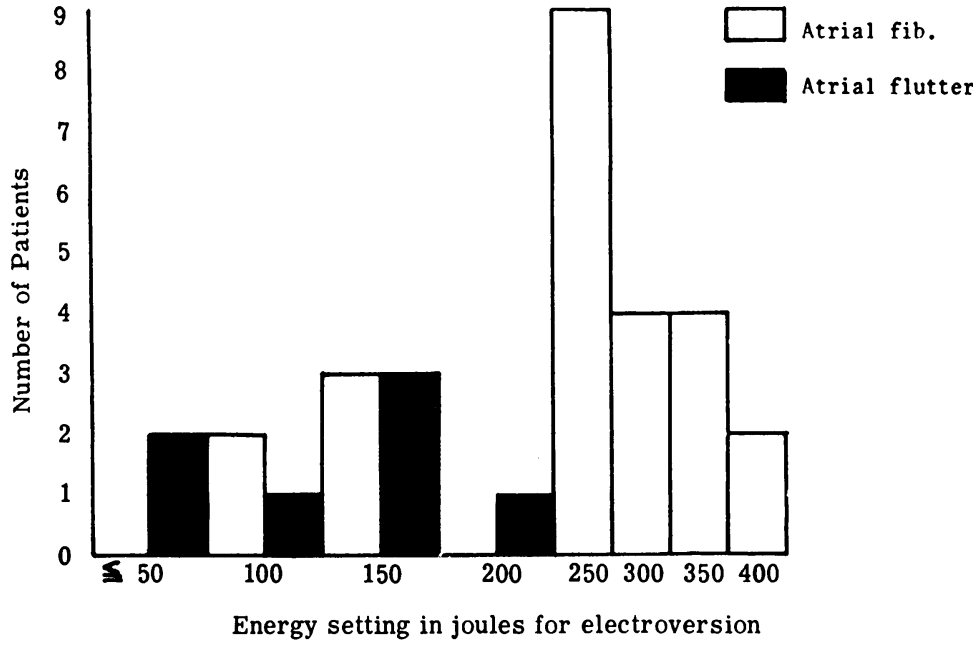

FI 3 Electrical energy setting for conversion of atrial fibrillation and flutter to sinus rhythm.

TABLE 2 Complications after DC shock in 5 of 30 patients treated for atrial fibrillation

\begin{tabular}{|c|c|c|c|c|}
\hline $\begin{array}{l}\text { Case } \\
\text { No. }\end{array}$ & $\begin{array}{l}\text { Duration of } \\
A F(y r .)\end{array}$ & $\begin{array}{l}\text { Maximum energy } \\
\text { setting (joules) }\end{array}$ & $\begin{array}{l}\text { Result } \\
\text { of } D C\end{array}$ & Complication \\
\hline 2 & $2 / 12$ & 400 & Sinus & Enzyme $\uparrow, 3$ rd heart sound \\
\hline 3 & 17 & 400 & Fail & Hypotension, enzyme $\uparrow$ \\
\hline 4 & I5 & 400 & Fail & $\begin{array}{l}\text { Hypotension, T wave } \downarrow \text {, } \\
\text { enzyme } \uparrow\end{array}$ \\
\hline 8 & 5 & 350 & Fail & Hypotension, enzyme $\uparrow$ \\
\hline 27 & $2 / 12$ & 350 & Sinus & T wave $\downarrow$, enzyme $\uparrow$ \\
\hline
\end{tabular}

FIG. 4 Reversion to atrial fibrillation

in 20 of the 24 patients brought into sinus rhythm. (a) Reversions each month over 36

months. (b) Reversions within the first month

( 16 of 20 patients). Note the high incidence of

reversion within the first 24 hours after

successful electroversion.
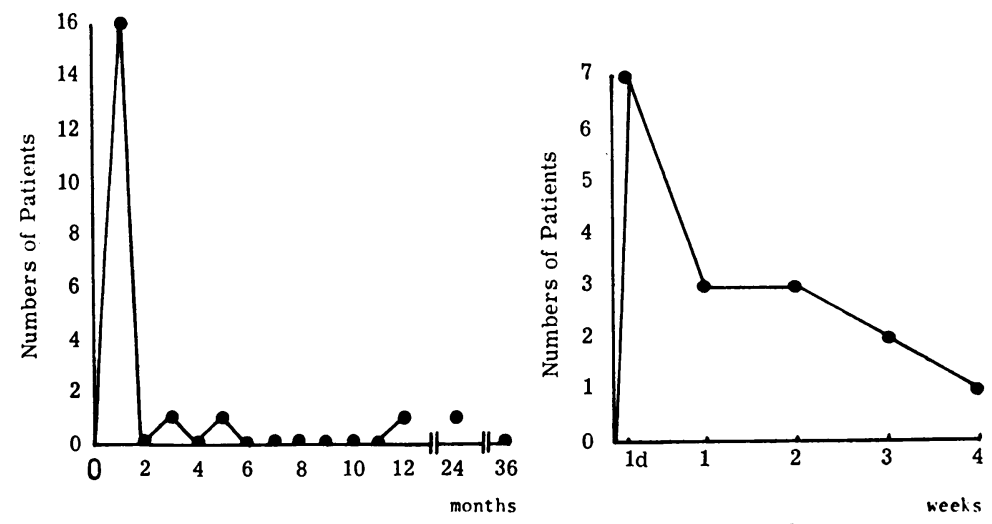

a. 
TABLE $3 \quad$ I 7 episodes of intervening rhythms among 30 patients treated for atrial fibrillation and 2 among 7 treated for atrial flutter

\begin{tabular}{lcl}
\hline Intervening rhythms & $\begin{array}{l}\text { Atrial } \\
\text { fibrillation }\end{array}$ & $\begin{array}{l}\text { Atrial } \\
\text { flutter }\end{array}$ \\
\hline Atrial extrasystoles & 8 & - \\
Ventricular extrasystoles & 6 & - \\
Wandering pacemaker & $\mathrm{I}$ & - \\
Sinus bradycardia & $\mathrm{I}$ & $\mathrm{I}$ \\
Nodal rhythm & - & $\mathrm{I}$ \\
Prolonged PR interval & $\mathrm{I}$ & - \\
$\quad$ Total & I7 & 2 \\
\hline
\end{tabular}

atrial flutter who converted to sinus rhythm, 2 have reverted to the dysrhythmia, one at three months and one at two months. The remaining 4 patients remain in sinus rhythm. A second electroversion was attempted in 7 patients with atrial fibrillation and one with atrial flutter. Of the 8 patients, 7 were brought into sinus rhythm, which persists only in one. The patient who failed to come into sinus rhythm despite maximum energies used reverted spontaneously to sinus rhythm three weeks after direct current shock.

\section{Haemodynamic results}

The mean and standard deviations of results and the significance of values during the dysrhythmia and in sinus rhythm at rest and at each work load are given in the text, in Table 5, and in Fig. 5-8.

Heart rate Heart rate was related linearly to work both during atrial fibrillation or flutter and in sinus rhythm. The average heart rate at rest was $100.5 / \mathrm{min}$. (SD 13.8 ), and after the establishment of sinus rhythm was $81 \cdot 2 / \mathrm{min}$. (SD $12 \cdot 7$ ). The difference was not

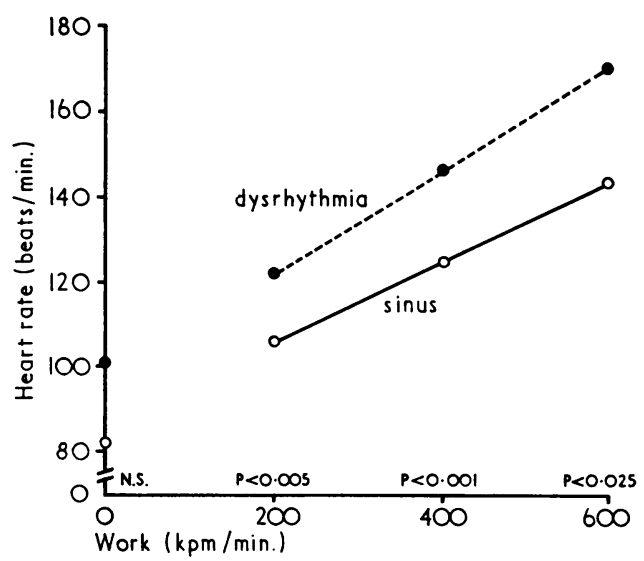

FIG. 5 Mean values of heart rate plotted against work performed during atrial fibrillation and flutter and repeated in sinus rhythm. N.S., not statistically significant.

FIG. 6 Mean values of cardiac output at rest and on effort in atrial fibrillation and flutter and in sinus rhythm.

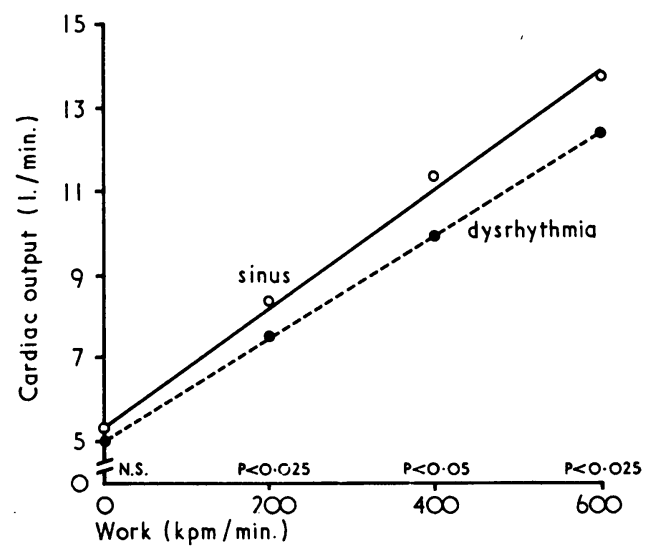

TABLE 47 patients who reverted to atrial fibrillation within the first day after electroconversion

\begin{tabular}{|c|c|c|c|c|c|}
\hline Case No. & $\begin{array}{l}\text { Duration } \\
\text { of } A F(m t h .)\end{array}$ & $\begin{array}{l}\text { Quinidine } \\
\text { before } \\
D C+-\end{array}$ & $\begin{array}{l}\text { DC energy } \\
\text { setting } \\
\text { (joules) }\end{array}$ & $\begin{array}{l}\text { Rhythm immediately } \\
\text { after } D C \text { shock }\end{array}$ & Comment \\
\hline $\mathbf{I}$ & 6 & - & 350 & $\begin{array}{l}\text { Sinus with infrequent } \\
\text { atrial extrasystoles }\end{array}$ & \\
\hline 9 & 19 & + & I50 & $\begin{array}{l}\text { Sinus with infrequent } \\
\text { atrial extrasystoles }\end{array}$ & \\
\hline I6 & 5 & - & 150 & Sinus, no extrasystoles & \\
\hline 17 & 6 & - & 350 & $\begin{array}{l}\text { Sinus with infrequent } \\
\text { ventricular extrasystoles }\end{array}$ & \\
\hline 23 & 16yr & - & 300 & $\begin{array}{l}\text { Sinus with atrial and } \\
\text { ventricular extrasystoles }\end{array}$ & \\
\hline 26 & 8 & - & 350 & Sinus, no extrasystoles & $\begin{array}{l}\text { 2nd DC on quinidine, } \\
\text { SR for } 2 \text { wk. }\end{array}$ \\
\hline
\end{tabular}




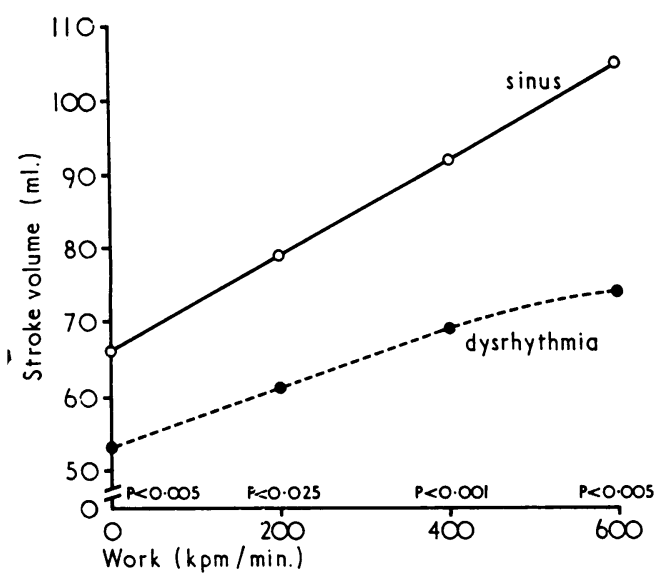

*IG. 7 Mean values of stroke volume at rest and on increasing work loads in atrial fibrillation and flutter and in sinus rhythm.

statistically significant. The difference, however, between the heart rates during the dysrhythmia and in sinus rhythm became texaggerated and statistically significant as the work load increased from 200 to $600 \mathrm{kpm}$./ min. (Fig. 5).

Oxygen consumption There was no significant difference in oxygen consumption at rest or on effort during the dysrhythmia or in sinus rhythm (Table 5).

Arteriovenous oxygen difference No significant difference was found between the arteriovenous oxygen difference at rest during the dysrhythmia (mean $67.9 \mathrm{ml}$.) and in sinus

1FIG. 8 Mean values of stroke volume plotted against heart rate at rest and on effort in atrial fibrillation and flutter and in sinus rhythm.

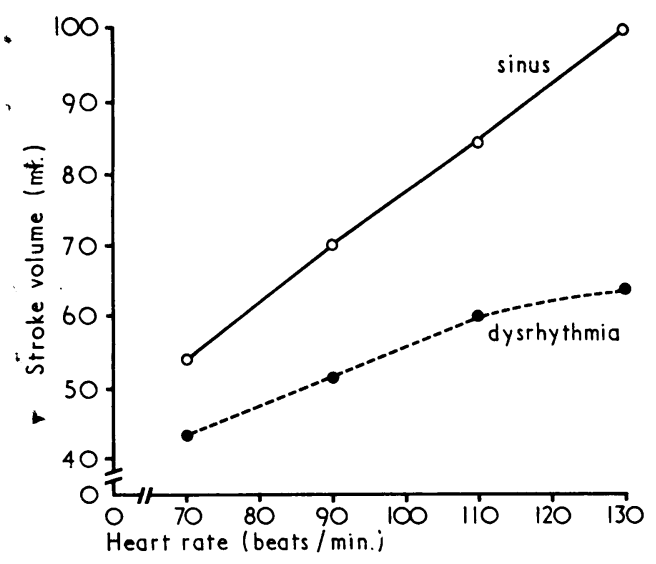

rhythm (mean $67.8 \mathrm{ml}$ ) (Table 5). Significant differences $(p<0.001)$, however, were seen during effort, and at $600 \mathrm{kpm} . / \mathrm{min}$. the arteriovenous oxygen difference averaged $133.2 \mathrm{ml}$. during the dysrhythmia (SD 22.5) and I $16.6 \mathrm{ml}$. during sinus rhythm (SD I7.8).

Cardiac output The mean cardiac output at rest during the dysrhythmia was $5.11 . / \mathrm{min}$. and $5.21 . / \mathrm{min}$. during sinus rhythm, and the difference is not statistically significant. A significant difference was found, however, at $600 \mathrm{kpm} . / \mathrm{min}$., the cardiac output averaging 12.3 $\mathrm{l} / \mathrm{min}$. during the dysrhythmia and I4.3 1./min. during sinus rhythm (Fig. 6).

Stroke volume The stroke volume averaged 52.8 at rest during the dysrhythmia (SD II.I) and 66.2 during sinus rhythm (SD I2.0), and at $600 \mathrm{kpm} . / \mathrm{min}$. was 74.3 (SD 20.0) during the dysrhythmia and $105 \cdot 3$ (SD 29.2) during sinus rhythm, this difference being statistically significant (Fig. 7). When the stroke volumes are compared at equivalent heart rates during sinus rhythm and during the dysrhythmia (Fig. 8), the beneficial effect of sinus rhythm is clearly shown, particularly at higher heart rates.

Physical work capacity The PWC 170 (Sjöstrand, 1947) averaged 631.3 during the dysrhythmia (SD 304.0) and 879.2 (SD 200.2) during sinus rhythm, and the difference is statistically significant $(p<0.05)$ (Table 5$)$.

Pressure measurements Brachial systolic, diastolic, and mean pressures, and pulmonary arterial systolic, diastolic, and mean pressures were measured with reference to the sternal angle at rest and at each of the three work loads during the dysrhythmia and in sinus rhythm (Table 5). One patient developed systemic hypertensive pressure levels on exercise, and in one, borderline hypertensive levels were recorded. Neither patient had any evidence of hypertension in the past. In one patient the pulmonary arterial pressure was marginally raised at rest, but it did not increase significantly during exercise. No consistent changes were recorded between the levels of the pressures at rest or on effort during the dysrhythmia or after the establishment of sinus rhythm.

\section{Discussion}

Though the first report of atrial fibrillation in association with an otherwise healthy heart is usually attributed to Gossage and Hicks (I9I3), both Fox (I9IO) and Mackenzie (I9II) 
TABLE 5 Haemodynamic results

\begin{tabular}{|c|c|c|c|c|c|c|c|c|c|c|c|c|c|c|c|c|c|c|}
\hline \multirow{3}{*}{$\begin{array}{l}\text { Case No., age (yr.), } \\
\text { sex, rhythm }\end{array}$} & \multicolumn{8}{|c|}{ Heart rate/min. } & \multicolumn{8}{|c|}{ Oxygen consumption (ml./min.) } & \multirow{2}{*}{\multicolumn{2}{|c|}{$\frac{\text { Arterio- }}{C}$}} \\
\hline & \multicolumn{2}{|l|}{$C$} & \multicolumn{2}{|l|}{200} & \multicolumn{2}{|l|}{400} & \multicolumn{2}{|l|}{600} & \multicolumn{2}{|l|}{$C$} & \multicolumn{2}{|l|}{200} & \multicolumn{2}{|l|}{400} & \multicolumn{2}{|l|}{600} & & \\
\hline & $\boldsymbol{D}$ & $S R$ & $D$ & $S R$ & $D$ & $S R$ & $D$ & $S R$ & $D$ & $S R$ & $D$ & $S R$ & $D$ & $S R$ & $D$ & $S R$ & $D$ & $S R$ \\
\hline I9, 55, M, AFib. & 80 & 68 & 100 & 100 & 122 & 118 & 145 & 134 & 343 & 334 & 780 & 755 & 1190 & 1185 & 1585 & 1580 & $65 \cdot 8$ & $63 \cdot 0$ \\
\hline 18, 60, M, AFib. & IIO & $7 \mathbf{I}$ & 140 & 100 & 160 & 117 & 180 & 135 & 357 & 350 & 875 & 882 & 1392 & 1398 & 1810 & 1830 & 75.0 & $70 \cdot 0$ \\
\hline $22,42, M, A F i b$. & 95 & 90 & 115 & 102 & 132 & 116 & 150 & 132 & 333 & 349 & 769 & 814 & 1148 & 1320 & 1594 & 1780 & $67 \cdot 4$ & $76 \cdot 0$ \\
\hline $24,44, M$, AFib. & 105 & 78 & 130 & 100 & 160 & 123 & 190 & 140 & 355 & 380 & 860 & 885 & 1210 & 1203 & 1655 & 1680 & $73 \cdot 4$ & 63.2 \\
\hline $34,60, M$, AFlut. & 133 & 88 & 142 & 108 & 155 & 120 & 170 & 135 & 380 & 386 & 791 & 802 & II9I & 1190 & 1585 & 1578 & 65.5 & 65.7 \\
\hline 36,47, F, AFlut. & 80 & 92 & 128 & 120 & 150 & 146 & 172 & 171 & 324 & 303 & 670 & 623 & 998 & 1028 & 1340 & 1360 & $60 \cdot 1$ & $69 \cdot 0$ \\
\hline $\begin{array}{l}\text { Mean } \\
\text { SD }\end{array}$ & $\begin{array}{r}100.5 \\
13.8\end{array}$ & $\begin{array}{l}81 \cdot 2 \\
12 \cdot 7\end{array}$ & $\begin{array}{r}125.8 \\
15.9\end{array}$ & $\begin{array}{r}105.0 \\
8.0\end{array}$ & $\begin{array}{r}146.5 \\
15.9\end{array}$ & $\begin{array}{r}123 \cdot 3 \\
11 \cdot 4\end{array}$ & $\begin{array}{r}167 \cdot 8 \\
17 \cdot 3\end{array}$ & $\begin{array}{r}141 \cdot 2 \\
14 \cdot 9\end{array}$ & $\begin{array}{r}348 \cdot 7 \\
19 \cdot 9\end{array}$ & $\begin{array}{r}350 \cdot 3 \\
30 \cdot 6\end{array}$ & $\begin{array}{r}709 \cdot 8 \\
73 \cdot 6\end{array}$ & $\begin{array}{r}793.5 \\
97 \cdot 2\end{array}$ & $\begin{array}{r}1188 \\
127\end{array}$ & $\begin{array}{r}1221 \\
127\end{array}$ & $\begin{array}{r}1594 \\
152\end{array}$ & $\begin{array}{r}1635 \\
169\end{array}$ & $\begin{array}{r}67.9 \\
5.5\end{array}$ & $\begin{array}{r}67 \cdot 8 \\
6.7\end{array}$ \\
\hline $\mathbf{p}$ & NS & & $<0.00$ & & $<0.00$ & & $<0.02$ & & NS & & NS & & NS & & NS & & NS & \\
\hline
\end{tabular}

\begin{tabular}{|c|c|c|c|c|c|c|c|c|c|c|c|c|c|c|c|c|c|c|c|c|c|c|c|c|}
\hline \multirow{3}{*}{$\begin{array}{l}\text { Case No., } \\
\text { age (yr.), sex, } \\
\text { rhythm }\end{array}$} & \multicolumn{8}{|c|}{$\begin{array}{l}\text { Systolic pulmonary arterial pressure } \\
(\mathrm{mm} . \mathrm{Hg})\end{array}$} & \multicolumn{8}{|c|}{$\begin{array}{l}\text { Diastolic pulmonary arterial pressure } \\
(\mathrm{mm} . \mathrm{Hg})\end{array}$} & \multicolumn{8}{|c|}{$\begin{array}{l}\text { Mean pulmonary arterial pressure } \\
(\mathrm{mm} . \mathrm{Hg})\end{array}$} \\
\hline & \multicolumn{2}{|l|}{$C$} & \multicolumn{2}{|l|}{200} & \multicolumn{2}{|l|}{400} & \multicolumn{2}{|l|}{600} & \multicolumn{2}{|l|}{$C$} & \multicolumn{2}{|l|}{200} & \multicolumn{2}{|l|}{400} & \multicolumn{2}{|l|}{600} & \multicolumn{2}{|l|}{$C$} & \multicolumn{2}{|l|}{200} & \multicolumn{2}{|l|}{400} & \multicolumn{2}{|l|}{600} \\
\hline & $D$ & $S R$ & $D$ & $S R$ & $D$ & $S R$ & $D$ & $S R$ & $D$ & $S R$ & $D$ & $S R$ & $D$ & $S R$ & $D$ & $S R$ & $D$ & $S R$ & $D$ & $S R$ & $D$ & $S R$ & $D$ & $S R$ \\
\hline \multirow{6}{*}{$\begin{array}{l}\text { 19, 55, M, AF } \\
\text { 18, 60, M, AF } \\
\text { 22, 42, M, AF } \\
\text { 24, 44, M, AF } \\
\text { 34, 60, M, } \\
\text { AFlut. } \\
\text { 36, 47, F, } \\
\text { AFlut. }\end{array}$} & 20 & 20 & 20 & 20 & 22 & 23 & 25 & 26 & Io & I0 & 10 & 10 & 10 & 12 & 12 & 12 & 14 & 14 & 14 & 14 & 14 & 16 & 16 & 16 \\
\hline & 18 & 15 & 20 & 18 & 20 & 18 & 20 & 20 & 8 & 6 & 8 & 8 & 8 & 8 & I0 & 10 & I0 & IO & 10 & IO & 10 & II & 12 & 12 \\
\hline & 15 & 12 & 17 & 15 & 18 & 15 & 22 & 20 & 8 & 8 & I0 & 10 & 10 & 8 & 12 & 10 & 10 & IO & 12 & 12 & 12 & 12 & 12 & 14 \\
\hline & 20 & 18 & 25 & 25 & 28 & 28 & 30 & 25 & 12 & 10 & 16 & 18 & 16 & 18 & 20 & 16 & 16 & 13 & 19 & 20 & 19 & 22 & 22 & $2 I$ \\
\hline & 35 & 33 & 35 & 35 & 35 & 35 & 33 & 35 & 16 & 15 & 10 & 10 & 10 & I0 & 10 & 10 & 22 & 22 & 21 & 22 & 21 & 22 & 21 & 22 \\
\hline & 20 & 20 & 30 & 25 & 37 & 25 & 37 & 25 & 8 & 6 & 12 & I0 & 5 & 10 & 10 & I0 & 12 & 12 & 18 & 14 & 22 & 14 & 20 & 14 \\
\hline $\begin{array}{l}\text { Mean } \\
\text { SD }\end{array}$ & $\begin{array}{r}21 \cdot 3 \\
7 \cdot 0\end{array}$ & $\begin{array}{r}19 \cdot 7 \\
7 \cdot 2\end{array}$ & $\begin{array}{r}24.5 \\
6.9\end{array}$ & $\begin{array}{r}23 \cdot 0 \\
7 \cdot 1\end{array}$ & $\begin{array}{r}26 \cdot 7 \\
8 \cdot 0\end{array}$ & $\begin{array}{r}24 \cdot 0 \\
7 \cdot 1\end{array}$ & $\begin{array}{r}27.8 \\
6.6\end{array}$ & $\begin{array}{r}23 \cdot 8 \\
4 \cdot 9\end{array}$ & $\begin{array}{r}10 \cdot 3 \\
3 \cdot 2\end{array}$ & $\begin{array}{l}9 \cdot 2 \\
3 \cdot 3\end{array}$ & $\begin{array}{r}11 \cdot 0 \\
3 \cdot 1\end{array}$ & $\begin{array}{r}11 \cdot 0 \\
3 \cdot 2\end{array}$ & $\begin{array}{r}16 \cdot 5 \\
3 \cdot 2\end{array}$ & $\begin{array}{r}11 \cdot 0 \\
4 \cdot 0\end{array}$ & $\begin{array}{r}12.3 \\
3.9\end{array}$ & $\begin{array}{r}11 \cdot 3 \\
2 \cdot 4\end{array}$ & $\begin{array}{r}14 \cdot 0 \\
4 \cdot 6\end{array}$ & $\begin{array}{r}13.5 \\
4.5\end{array}$ & $\begin{array}{r}15 \cdot 7 \\
4 \cdot 3\end{array}$ & $\begin{array}{r}15 \cdot 3 \\
4.7\end{array}$ & $\begin{array}{r}16 \cdot 3 \\
5 \cdot 0\end{array}$ & $\begin{array}{r}16 \cdot 2 \\
4 \cdot 8\end{array}$ & $\begin{array}{r}17 \cdot 2 \\
4 \cdot 5\end{array}$ & $\begin{array}{r}16 \cdot 5 \\
4 \cdot 1\end{array}$ \\
\hline p & \multicolumn{2}{|l|}{ NS } & \multicolumn{2}{|l|}{ NS } & \multicolumn{2}{|l|}{ NS } & \multicolumn{2}{|l|}{ NS } & \multicolumn{2}{|l|}{ NS } & \multicolumn{2}{|l|}{ NS } & \multicolumn{2}{|l|}{ NS } & \multicolumn{2}{|l|}{ NS } & \multicolumn{2}{|l|}{ NS } & \multicolumn{2}{|l|}{ NS } & \multicolumn{2}{|l|}{ NS } & \multicolumn{2}{|l|}{ NS } \\
\hline
\end{tabular}

Case numbers refer to Table I.

were clearly aware of this condition, and, indeed, Wenckebach (1904) described a patient with 'delirium cordis' in the absence of detectable underlying heart disease and illustrated the account with a pulse tracing which almost certainly shows atrial fibrillation, as quoted by Denham (1964). Since then, many reports have appeared confirming the occurrence of the dysrhythmia without clinically detectable underlying heart disease (Fowler and Baldridge, I930; Parkinson and Campbell, 1930; Friedlander and Levine, 1934; Orgain, Wolff, and White, 1936; Hanson and Rutledge, 1949; Evans and Swann, 1954). The condition is frequently called 'uncomplicated' (Orgain et al., 1936) or 'idiopathic' (Peter, Gracey, and Beach, 1968), though Evans and Swann (1954) preferred the term 'lone'. The underlying forms of cardiac disease most commonly associated with atrial fibrillation are mitral stenosis, thyrotoxicosis, coronary heart disease, systemic hypertension, cardiomyopathy, constrictive pericarditis, atrial septal defect, and pulmonary hypertension of whatever cause, all of which have to be carefully excluded before a diagnosis of lone atrial fibrillation can be substantiated. Even careful postmortem studies of these patients have failed to reveal any recognizable cause (Neufeld et al., 196I). A minor conduction defect, difficult to detect without special histological studies, might well be responsible for some of the patients diagnosed as 'lone'. This was the probable cause in Case $I$ of our series, a young woman of 22 years with atrial fibrillation but no detectable underlying heart disease. An earlier electrocardiogram, however, at the age of 6 demonstrated an abnormally short $P R$ interval but without widening or slurring of the QRS complex of the type described by Lown, Ganong, and Levine (1952) as being associated with paroxysmal or established atrial dysrhythmias.

It is important to distinguish between lone atrial fibrillation which is established and the paroxysmal variety (Evans and Swann, 1954). Paroxysmal lone atrial fibrillation is twice as common as the established form (Hanson and 


\begin{tabular}{|c|c|c|c|c|c|c|c|c|c|c|c|c|c|c|c|c|c|c|c|c|c|c|c|}
\hline \multicolumn{6}{|c|}{ venous oxygen difference (ml.) } & \multicolumn{8}{|c|}{ Cardiac output (l./min.) } & \multicolumn{8}{|c|}{ Stroke volume (ml.) } & \multicolumn{2}{|c|}{$P W C_{I 70}$} \\
\hline \multicolumn{2}{|l|}{200} & \multicolumn{2}{|l|}{400} & \multicolumn{2}{|l|}{600} & \multicolumn{2}{|l|}{$C$} & \multicolumn{2}{|l|}{200} & \multicolumn{2}{|l|}{400} & \multicolumn{2}{|l|}{600} & \multicolumn{2}{|l|}{$C$} & \multicolumn{2}{|l|}{200} & \multicolumn{2}{|l|}{400} & \multicolumn{2}{|l|}{600} & \multirow[b]{2}{*}{$D$} & \multirow[b]{2}{*}{$S R$} \\
\hline$D$ & $S R$ & $D$ & $S R$ & $D$ & $S R$ & $D$ & $S R$ & $D$ & $S R$ & $D$ & $S R$ & $D$ & $S R$ & $D$ & $S R$ & $D$ & $S R$ & $D$ & $S R$ & $D$ & $S R$ & & \\
\hline $\begin{array}{r}90.0 \\
116.0 \\
98.6 \\
116.2 \\
113.6 \\
100.3\end{array}$ & $\begin{array}{r}80.0 \\
\text { IOI.3 } \\
94.7 \\
\text { IIO.8 } \\
\text { IOI.8 } \\
95.0\end{array}$ & $\begin{array}{l}100.0 \\
136.0 \\
105.2 \\
123.8 \\
140.8 \\
114.7\end{array}$ & $\begin{array}{r}86.7 \\
113.0 \\
102.3 \\
120.7 \\
119.0 \\
113.0\end{array}$ & $\begin{array}{l}104.2 \\
I 40 \cdot 8 \\
I 14.0 \\
I 34.5 \\
I 70 \cdot 1 \\
I 35.8\end{array}$ & $\begin{array}{r}89.0 \\
114.0 \\
106.7 \\
138.5 \\
131.5 \\
120.0\end{array}$ & $\begin{array}{l}5 \cdot 2 \\
4 \cdot 8 \\
4 \cdot 9 \\
4 \cdot 7 \\
5 \cdot 8 \\
5 \cdot 4\end{array}$ & $\begin{array}{l}5 \cdot 3 \\
5 \cdot 0 \\
4.6 \\
6 \cdot 0 \\
5 \cdot 9 \\
4 \cdot 4\end{array}$ & $\begin{array}{l}8 \cdot 7 \\
7 \cdot 6 \\
7 \cdot 8 \\
7 \cdot 4 \\
7 \cdot 0 \\
6 \cdot 7\end{array}$ & $\begin{array}{l}9.4 \\
8.7 \\
8.6 \\
8.0 \\
7.9 \\
6.6\end{array}$ & $\begin{array}{r}11.9 \\
10.2 \\
10.9 \\
9.8 \\
8.1 \\
8.5\end{array}$ & $\begin{array}{r}13.7 \\
12.4 \\
12.8 \\
10.0 \\
10.0 \\
9.0\end{array}$ & $\begin{array}{r}15.2 \\
12.9 \\
14.0 \\
12.3 \\
9.3 \\
9.9\end{array}$ & $\begin{array}{l}17 \cdot 8 \\
16 \cdot 1 \\
16 \cdot 7 \\
12 \cdot 1 \\
12 \cdot 0 \\
11 \cdot 3\end{array}$ & $\begin{array}{l}65 \\
43 \\
52 \\
45 \\
44 \\
68\end{array}$ & $\begin{array}{l}78 \\
71 \\
56 \\
77 \\
67 \\
48\end{array}$ & $\begin{array}{l}87 \\
54 \\
68 \\
57 \\
49 \\
52\end{array}$ & $\begin{array}{l}94 \\
87 \\
84 \\
80 \\
72 \\
55\end{array}$ & $\begin{array}{l}97 \\
64 \\
83 \\
61 \\
52 \\
57\end{array}$ & $\begin{array}{r}116 \\
100 \\
110 \\
81 \\
83 \\
62\end{array}$ & $\begin{array}{r}104 \\
72 \\
93 \\
65 \\
55 \\
57\end{array}$ & $\begin{array}{r}133 \\
119 \\
139 \\
86 \\
89 \\
66\end{array}$ & $\begin{array}{l}810 \\
500 \\
820 \\
468 \\
600 \\
590\end{array}$ & $\begin{array}{r}1020 \\
990 \\
1050 \\
965 \\
660 \\
590\end{array}$ \\
\hline $\begin{array}{r}105.8 \\
11.0\end{array}$ & $\begin{array}{l}97.5 \\
16.4\end{array}$ & $\begin{array}{r}120 \cdot 1 \\
13.8\end{array}$ & $\begin{array}{r}109 \cdot 1 \\
12 \cdot 7\end{array}$ & $\begin{array}{r}133.2 \\
22.5\end{array}$ & $\begin{array}{r}116.6 \\
17.8\end{array}$ & $\begin{array}{l}5 \cdot 1 \\
0.4\end{array}$ & $\begin{array}{l}5.2 \\
0.4\end{array}$ & $\begin{array}{l}7.5 \\
0.7\end{array}$ & $\begin{array}{l}8 \cdot 2 \\
1 \cdot 0\end{array}$ & $\begin{array}{l}9.9 \\
1 \cdot 4\end{array}$ & $\begin{array}{r}I I \cdot 3 \\
0.6\end{array}$ & $\begin{array}{r}12 \cdot 3 \\
2 \cdot 3\end{array}$ & $\begin{array}{r}14.3 \\
2.8\end{array}$ & $\begin{array}{l}52 \cdot 8 \\
\mathrm{II} \cdot \mathrm{I}\end{array}$ & $\begin{array}{l}66 \cdot 2 \\
12 \cdot 0\end{array}$ & $\begin{array}{l}6 I \cdot 2 \\
I 4 \cdot 2\end{array}$ & $\begin{array}{l}78 \cdot 7 \\
13 \cdot 7\end{array}$ & $\begin{array}{l}69.0 \\
17.3\end{array}$ & $\begin{array}{l}92 \cdot 0 \\
20.3\end{array}$ & $\begin{array}{l}74.3 \\
20.0\end{array}$ & $\begin{array}{r}105 \cdot 3 \\
29 \cdot 2\end{array}$ & $\begin{array}{l}631 \cdot 3 \\
304 \cdot 0\end{array}$ & $\begin{array}{l}879 \cdot 2 \\
200 \cdot 2\end{array}$ \\
\hline \multicolumn{2}{|c|}{$<0.001$} & \multicolumn{2}{|l|}{$<0.05$} & \multicolumn{2}{|c|}{$<0.001$} & \multicolumn{2}{|l|}{ NS } & \multicolumn{2}{|c|}{$<0.025$} & \multicolumn{2}{|c|}{$<0.05$} & \multicolumn{2}{|c|}{$<0.025$} & \multicolumn{2}{|c|}{$<0.005$} & \multicolumn{2}{|c|}{$<0.025$} & \multicolumn{2}{|c|}{$<0.001$} & \multicolumn{2}{|c|}{$<0.005$} & \multicolumn{2}{|c|}{$<0.05$} \\
\hline
\end{tabular}

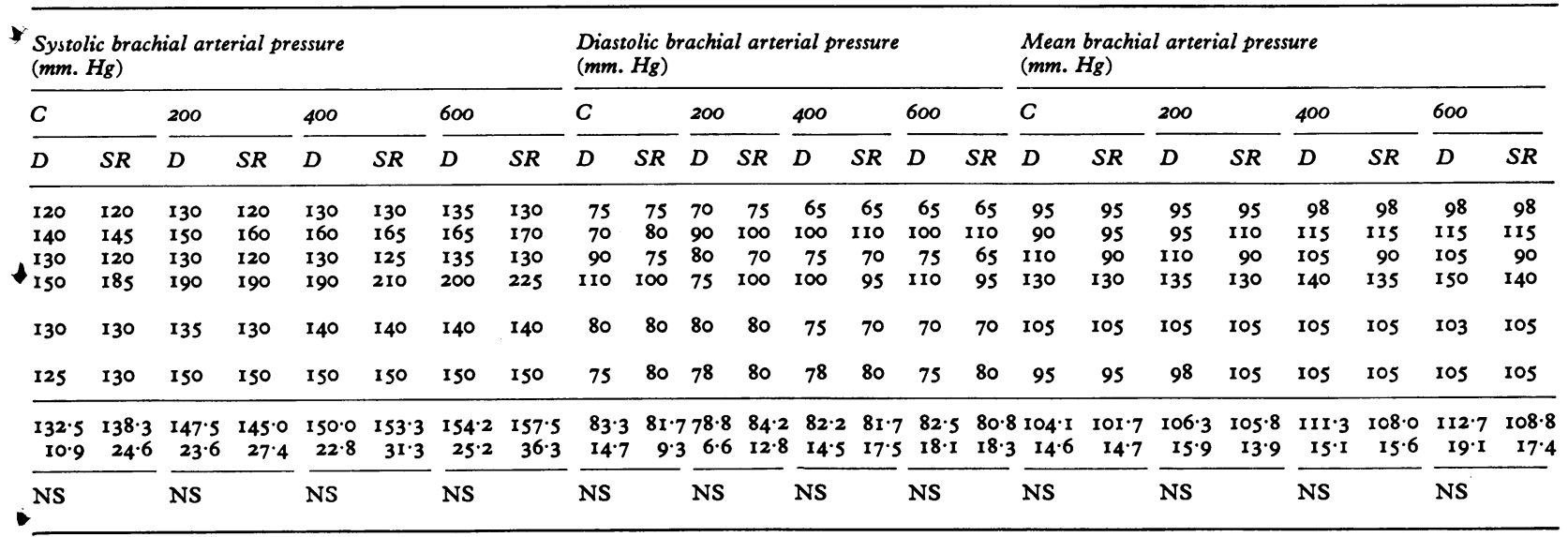

C, Control; 200, 400, 600, exercise level (kpm./min.); D, dysrhythmia; $\mathrm{PWC}_{170}$, physical work capacity at heart rate of 170/min.; SR, sinus rhythm.

Rutledge, 1949); and atrial fibrillation is unassociated with demonstrable heart disease in 5 per cent of all patients who present with this shythm disturbance. There is an overwhelming male preponderance in lone atrial fibrillation as reported first by Parkinson and Campbell (1930), and in many series men outnumber women by 9 to I. Various stimuli - have been proposed as the cause for paroxysmal atrial fibrillation in an otherwise normal - heart as reviewed by Orgain et al. (1936), including infections (Parkinson and Campbell, 1930), digitalis, as noted by Brams and Gaberman and quoted by McEachern and Baker (1932), alcohol (Wolferth, 1925), trauma (Bramwell, I934), gallbladder colic (Felberbaum and Finesilver, 1927), and emotion (Heitz, I9r4). A high incidence of recurrent paroxysmal atrial fibrillation has recently been reported in flying personnel by Lamb and Pollard (1964). Familial atrial fibrillation is of particular interest, and though rare, has been reported by Phair (1963), and by Gould (1957) who traced 22 cases of atrial fibrillation through 5 generations of one family.

Lone atrial flutter is less common (Parkinson and Bedford, 1927; Sprague and White, 1928). As with atrial fibrillation, it occurs either as a paroxysmal or an established dysrhythmia, and once more there is a conspicuous preponderance of male patients.

The lone atrial rhythm disturbances may continue for many years without precipitating cardiac decompensation, and Levine (1963) has reported the necropsy findings in a patient in whom atrial fibrillation had occurred for 40 years before death. The heart weighed $490 \mathrm{~g}$. and no cardiac cause for the rhythm disturbance or for the death of the patient was determined. Similar reports have appeared (Neufeld et al., 196r ; Frothingham, 1925; Yater, 1929). Before the availability of electrical methods for converting rhythm disturbances, it was recommended that digitalis preparations and quinidine be given to restore sinus rhythm in patients with lone atrial fibrillation or flutter to improve cardiac 
function when compromised or prophylactically to prevent the development of emboli (Phillips and Levine, 1949). Evans and Swann (1954), however, were opposed to any attempt at converting these patients, and Askey (1962) expressed doubt about the role of thrombus formation in the left or the right atrium as being responsible for the occurrence of pulmonary or systemic emboli.

The introduction of synchronized capacitor discharge for the planned conversion of atrial and ventricular rhythm disturbances (Lown et al., 1962) has been a most significant advance in the management of all cardiac rhythm disturbances. It is more effective than quinidine (McDonald et al., 1964), and the overall success rate of conversion to sinus rhythm approaches 90 per cent (Resnekov and McDonald, 1968). Treatment by synchronized capacitor discharge, however, is not entirely free of complications (Resnekov and McDonald, 1967), among which may be listed pulmonary oedema in sinus rhythm, myocardial damage, hypotension, and systemic embolism, and the incidence of complications relates particularly to the level of energy used (Resnekov, 1965). In a series of 220 consecutive patients treated by synchronized capacitor discharge, there was an overall complication rate of 14.5 per cent (Resnekov and McDonald, 1967); at energy settings of between 50 and 250 joules, 8 per cent developed complications; when the setting was 300 to 400 joules, the complication rate rose to 33 per cent. Careful selection of patients for this form of treatment is, therefore, required.

It has previously been shown (Resnekov, 1965) that successful reversion to sinus rhythm following DC shock in patients with atrial fibrillation could be related to the duration of the dysrhythmia and the overall size of the heart with particular reference to the size of the left atrium. Idiopathic atrial fibrillation might, therefore, be considered an ideal dysrhythmia for treatment by synchronized DC shock. Nevertheless, the 30 patients in this series show that treatment with DC shock is disappointing, for the incidence of success was low and that of complications high, which could be related to the levels of energy needed, and furthermore, sinus rhythm persisted only for a short duration in the majority of patients. Idiopathic atrial fibrillation is thus relatively resistant to treatment by DC shock suggesting that there may be an underlying conduction defect responsible for precipitating or maintaining the dysrhythmia. Though the heart can be depolarized by the electrical current, it appears that the sinoatrial node is not capable of taking over permanently as pacemaker and atrial fibrillation persists or soon returns. Patients in whom apparent sinus rhythm was restored still had a high incidence of reversion to atrial fibrillation, and this occurred particularly within the first 24 hours, or within the first four weeks, nor was quinidine very beneficial in maintaining sinus rhythm.

In contrast, the patients with atrial flutter proved to be a more successful group for electroversion. All were brought into sinus rhythm, the energy setting required was low, and the incidence of reversion to atrial flutter was much less high than in patients with atrial fibrillation.

With these relatively poor results, particularly treating atrial fibrillation, it seemed important to know whether any haemodynamic benefit would follow the conversion of lone atrial rhythm disturbances to sinus rhythm. Four patients with atrial fibrillation and two with atrial flutter were therefore studied at rest and on graded exercise before and after conversion. Clear evidence of haemodynamic benefit was obtained as shown by a slower heart rate at equivalent exercise loads associated with a higher cardiac output and a larger stroke volume. Comparing the stroke volumes in the two series during rest and exercise but at identical heart rates showed the haemodynamic benefit of sinus rhythm produced by an appropriately timed atrial systole. Patients with idiopathic atrial fibrillation and flutter behave similarly in this respect to patients where the atrial dysrhythmia is associated with known heart disease (Resnekov, 1967). Earlier reports (Baer, Weglarz, and Killip, 1964; Killip and Baer, 1966) failed to show haemodynamic improvement after the conversion of idiopathic atrial fibrillation to sinus rhythm. possibly due to the relatively low levels of exercise used, for in our series it was only on severe exercise that the beneficial action of atrial systole could be established. In contrast, in the presence of heart disease or diminished compliance of the ventricle, atrial systole may be important even at rest (Braunwald and Frahm, 1961), and the effect becomes more evident with increasing work loads, either with or without underlying heart disease (Resnekov, 1965). The two patients with atrial flutter behaved in a similar manner to those with atrial fibrillation, with a demonstrable distinct haemodynamic benefit in sinus rhythm, especially at the higher loads of exercise.

Though sinus rhythm is haemodynamically to be preferred, particularly on severe 
exertion, the present series indicates that there is no indication for the conversion to sinus rhythm of uncomplicated lone atrial fibrillation by direct current shock. McCarthy, Varghese, and Barritt (1969) recommended the DC conversion of these patients, but analysis of their published results, separating patients with lone atrial fibrillation from those with atrial flutter, indicates that such treatment is often disappointing, thus confirming

- the pre-DC shock opinion of Evans and Swann (1954) as well as the current view of Lown (1967) and of Radford and Evans (1968). In contrast, patients with lone atrial flutter are converted electrically with greater ease and maintain sinus rhythm more readily. Thus with lone atrial flutter electroversion is * a relative indication.

We wish to thank our medical and surgical colleagues who referred patients for investigation and treatment.

\section{References}

Askey, J. M. (1962). Editorial. Embolism and atrial fibrillation. The effect of restoration of normal rhythm by quinidine. American fournal of Cardiology, 9, 491.

Baer, R., Weglarz, S., and Killip, T. (1964). Cardiac function in atrial fibrillation and sinus rhythm (abstract). Clinical Research, 12, 175.

Berger, L., and Broida, D. (1957). Serum enzyme determinations. Sigma Technical Bulletin No. 340. Sigma Chemical Company, St. Louis.

Berger, L., and Broida, D. (I960). The colorimetric determination of lactic dehydrogenase in serum or other fluids. Sigma Technical Bulletin No. 500. Sigma Chemical Company, St. Louis.

Bramwell, C. (1934). Can a head injury cause auricular fibrillation ? Lancet, $\mathbf{I}, 8$.

Braunwald, E., and Frahm, C. J. (1961). Studies on Starling's law of the heart. IV. Observations on the hemodynamic functions of the left atrium in man. Circulation, 24, 633.

Broida, D. (1956). The determination of serum GOand GP-transaminase. Technical Bulletin No. 4 IO Sigma Chemical Company, St. Louis.

Broido, D. (196I). A simplified method for the colorimetric determination of glutamic and pyruvic transaminases. Sigma Technical Bulletin No. 505. Sigma Chemical Company, St. Louis.

Danzer, C. S. (I919). The cardiothoracic ratio: an index of cardiac enlargement. American fournal of

the Medical Sciences, 157, 513 .

Dawson, J. B. (I960). The E.S.R. in a new dress. British Medical fournal, I, 1697.

Denham, R. M. (1964). Atrial fibrillation without evidence of heart disease. Southern Medical fournal, 57,491 .

Du Bois, D., and Du Bois, E. F. (1916). Clinical calorimetry. Tenth paper: A formula to estimate the approximate surface area if height and weight

- be known. Archives of Internal Medicine, 17, 863.

Evans, W., and Swann, P. (1954). Lone auricular fibrillation. British Heart fournal, 16, 189.

Felberbaum, D., and Finesilver, B. (1927). Transient auricular fibrillation in abdominal diseases. American Heart fournal, 2, 4I6.
Fowler, W. M., and Baldridge, C. W. (1930). Auricular fibrillation as the only manifestation of heart disease. American Heart fournal, 6, 183.

Fox, G. H. (1910). The clinical significance of transitory delirium cordis. American fournal of the Medical Sciences, 140, 815 .

Friedlander, R. D., and Levine, S. A. (1934). Auricular fibrillation and flutter without evidence of organic heart disease. New England fournal of Medicine, 211, 624 .

Frothingham, C. (1925). The auricles in cases of auricular fibrillation. Archives of Internal Medicine, 36, 437.

Gilston, A., Fordham, R., and Resnekov, L. (1965). Anaesthesia for direct current shock in the treatment of cardiac arrhythmias. British fournal of Anaesthesia, 37, 533 .

Gossage, A. M., and Hicks, J. A. B. (1913). On auricular fibrillation. Quarterly fournal of Medicine, $6,435$.

Gould, W. L. (1957). Auricular fibrillation. Report on a study of a familial tendency, 1920-1956. Archives of Internal Medicine, 100, 916.

Hanson, H. H., and Rutledge, D. I. (1949). Auricular fibrillation in normal hearts. New England fournal of Medicine, 240, 947.

Heitz, J. (I914). La forme paroxystique de l'arythmie complète. Annales de Médecine, I, 483.

Hill, A. B. (1966). Principles of Medical Statistics, 8th ed., pp. 143-149. Lancet, London.

Killip, T., and Baer, R. A. (I966). Hemodynamic effects after reversion from atrial fibrillation to sinus rhythm by precordial shock. Fournal of Clinical Investigation, 45, 658.

Lamb, L. E., and Pollard, L. W. (1964). Atrial fibrillation in flying personnel. Report of 60 cases. Circulation, 29, 694.

Levine, S. A. (1963). Benign atrial fibrillation of forty years' duration with sudden death from emotion. Annals of Internal Medicine, 58, 681.

Lown, B. (1967). Electrical reversion of cardiac arrhythmias. British Heart fournal, 29, 469.

Lown, B., Amarasingham, R., and Neuman, J. (1962). New method for terminating cardiac arrhythmias. Use of synchronized capacitor discharge. Fournal of the American Medical Association, 182, 548.

Lown, B., Ganong, W. F., and Levine, S. A. (I952). The syndrome of short P-R interval, normal QRS complex and paroxysmal rapid heart action. Circulation, 5, 693.

McCarthy, C., Varghese, P. J., and Barritt, D. W. (1969). The prognosis of atrial arrhythmias treated by electrical countershock therapy. A three-year follow-up. British Heart fournal, 3I, 496.

McDonald, L., and Resnekov, L. (1965). Atrial defibrillation. In Resuscitation and Cardiac Pacing, p. 140. Ed. by G. Shaw, G. Smith, and T. J. Thomson. Cassell, London.

McDonald, L., Resnekov, L., and O'Brien, K. (1964). Direct-current shock in treatment of drug-resistant cardiac arrhythmias. British Medical fournal, I, 1468.

McEachern, D., and Baker, B. M. (1932). Auricular fibrillation. Its etiology, age incidence and production by digitalis therapy. American fournal of the Medical Sciences, 183, 35.

Mackenzie, J. (I9I I). Digitalis. Heart, 2, 273.

Neufeld, H. N., Wagenvoort, C. A., Burchell, H. B., and Edwards, J. E. (I96r). Idiopathic atrial fibrillation. American fournal of Cardiology, 8, 193.

Orgain, E. S., Wolff, L., and White, P. D. (1936). Uncomplicated auricular fibrillation and auricular flutter. Frequent occurrence and good prognosis in patients without other evidence of cardiac disease. Archives of Internal Medicine, 57, 493. 
Owren, P. A. (1959). Thrombotest, a new method for controlling anticoagulant therapy. Lancet, 2, 754.

Parkinson, J., and Bedford, D. E. (1927). The course and treatment of auricular flutter. Quarterly Fournal of Medicine, 21, 2 I.

Parkinson, J., and Campbell, M. (1930). Paroxysmal auricular fibrillation. A record of two hundred patients. Quarterly fournal of Medicine, 24, 67.

Peter, R. H., Gracey, J. G., and Beach, T. B. (1968). A clinical profile of idiopathic atrial fibrillation. A functional disorder of atrial rhythm. Annals of Internal Medicine, 68, 1288.

Phair, W. B. (1963). Familial atrial fibrillation. Canadian Medical Association fournal, 89, 1274.

Phillips, E., and Levine, S. A. (1949). Auricular fibrillation without other evidence of heart disease: a cause of reversible heart failure. American fournal of Medicine, 7, 478.

Radford, M. D., and Evans, D. W. (1968). Long-term results of DC reversion of atrial fibrillation. British Heart fournal, 30, 91.

Resnekov, L. (1965). Synchronised capacitor discharge in the management of cardiac arrhythmias with particular reference to the haemodynamic significance of atrial systole. M.D. Thesis, University of Cape Town.

Resnekov, L. (1967). Haemodynamic studies before and after electrical conversion of atrial fibrillation and flutter to sinus rhythm. British Heart fournal, 29, 700 .

Resnekov, L., and McDonald, L. (1967). Complications in 220 patients with cardiac dysrhythmias treated by phased direct current shock, and indications for electroconversion. British Heart fournal, 29, 926.

Resnekov, L., and McDonald, L. (1968). Appraisal of electroconversion in treatment of cardiac dysrhythmias. British Heart fournal, 30, 786.

Scholander, P. F. (1947). Analyzer for accurate estimation of respiratory gases in one-half cubic centimeter samples. Fournal of Biological Chemistry, 167, 235.

Seldinger, S. I. (1953). Catheter replacement of the needle in percutaneous arteriography. A new technique. Acta Radiologica, 39, 368.

Sjöstrand, T. (1947). Changes in the respiratory organs of workmen at an ore smelting works. Acta Medica Scandinavica, Suppl. 196, 687.

Sprague, H. B., and White, P. D. (1928). Auricular flutter: report of a case of five years' duration with spontaneous restoration of normal rhythm. Fournal of the American Medical Association, 90, 1772.

Van Slyke, D. D., and Neill, J. M. (1924). Determinaof gases in blood and other solutions by vacuum extraction and manometric measurement. Fournal of Biological Chemistry, 61, 523.

Wenckebach, K. F. (1904). Arhythmia of the Heart. Translated by $T$. Snowball. William Green and Sons, Edinburgh and London.

Wolferth, C. C. (1925). Intermittent auricular fibrillation. Archives of Internal Medicine, 36, 735.

Yater, W. M. (1929). Pathologic changes in auricular fibrillation and in allied arrhythmias. Archives of Internal Medicine, 43, 808. 